\title{
PROFESSOR ANTHONY GLUZIŃSKI: LIFE AND ACHIEVEMENTS OF THE FOUNDER OF THE POLISH SOCIETY OF INTERNAL MEDICINE
}

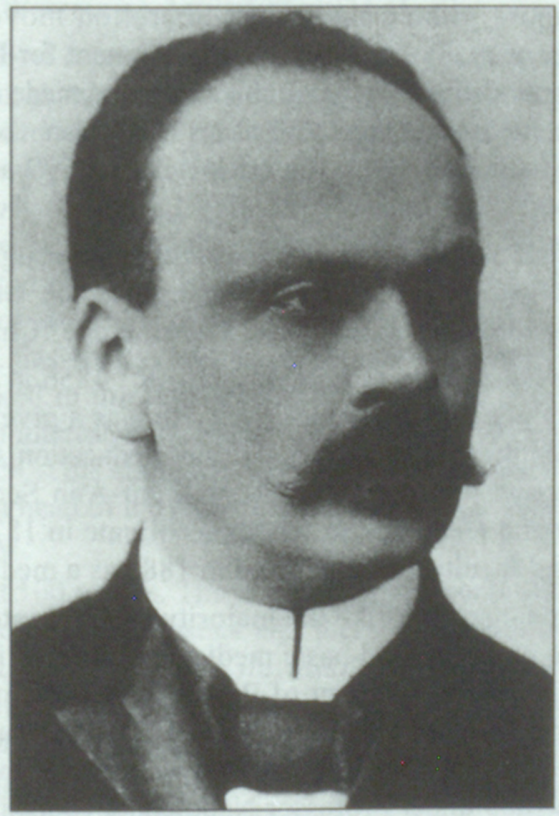

Professor Anthony Głuziński, photo made about 1890 (From collection of the Central Medical Library in Warsaw)

Professor Anthony Głuziński was one of the greatest Polish internists of the end of the $19^{\text {th }}$ century and the first decades of the $20^{\text {th }}$ century. He was a professor at three leading Polish universities, Cracow, Lvov and Warsaw, and the founder and the first president of the Polish Society of Internal Medicine as well as founder and the first editor-in-chief of the society journal, Polish Archives of Internal Medicine. 
Professor Głuziński was a descent of the medical family. His father, Dr. Francis Mathiew John Głuziński was born on January $14^{\text {th }}, 1823$ in Andrychów, a small city near Wadowice, located on the river Wieprzówka in a region of Cracow. He was a son of Francis and Catherine Wiercimak, the peasant family living in strong Polish tradition. Francis Głuziński participated in the liberation movement in Galicia and Hungary (1846-1848). He was imprisoned in Schlüsselburg. This caused that he enrolled himself at the Medical Faculty of the Cracow University just in 1850 . Two years latter, he changed his name "Wiercimak" to Głuziński (it was the family name of his mother and sounded significantly better in Polish). After graduation, he still felt threaded in the Austrian Empire thus he moved to the Russian part of partitioned Poland. He established himself in Sompolno in Kujawy, following nostrification of his diploma, and he had an active medical practice their [1]. In the years of the January Insurrection (1863), he once more jointed the Polish liberation movement. He was a commissary officer of the Polish National Government for Province of Kalisz and physician of wounded insurgents. In his house, he made a field hospital for them. In late years, he lived at the home of his oldest son, the famous internist. Dr. Francis Głuziński died in Lvov on May $22^{\text {nd }}, 1899$ and was buried in Cracow [2].

Dr. Francis Głuziński was married to Valeria Szarle, a daughter of the French military physician who had stayed in Poland since the Napoleon war. The name "Szarle" was a Polish version of the French name "Charlais".

Professor Anthony Głuziński was born on May $18^{\text {th }}, 1856$ in Włocławek, a city in Bydgoszcz Province on the Vistuła river. He was a given name Ladislaus Anthony but he used the middle name only. Early education Anthony Głuziński received in Konin and than he attended the Saint Ann Secondary Grammar School in Cracow and received the school certificate in 1874. In Cracow, he enrolled the medical faculty and graduated in 1880 as a medical doctor.

Professor Anthony Głuziński, like the majority of great internists, combined research in clinical medicine and basic medical sciences. His early researches were carried out in the Department of Pathophysiology at the Jagiellonian University in Cracow. He was working under Professor Gustavus Piotrowski (1833-1884) [3], a famous physiologist, known as a discoverer of the biuret reaction and since 1885 under Professor Napoleon Cybulski (1854-1923), the world-known physiologist and discoverer of adrenaline [4].

Professor Głuziński obtained his habilitation degree in pathology and therapy of internal diseases in 1885 . He was granted the title of extraordinary professor in 1890 and ordinary professor in 1893. Professor Głuziński was head of the Chair of General and Experimental Pathology at the Jagiellonian University in 1893-1897. In this period, he constantly co-worked with the Department of Medicine. He participated in a short training course in Berlin at the famous Institute of Bacteriology under Robert Koch (1843-1910). 
Professor Głuziński left Cracow in 1897 and became a head of the Department of Internal Medicine in Lvov. In a short time, his department became the leading centre of medical sciences. He was also active in the university life. In the years 1898-1899, Głuziński was a dean of the medical faculty and was elected to the post of rector magnificus in the years of 1905-1906. He was considered the best Polish internist and after restoration of independent Poland was proposed the post of the head of the Department of Internal Medicine at the Warsaw University. He accepted the proposal and moved to the capital despite still lasting military actions there. He started to organise a department in the Hospital of Infant Jesus in Warsaw in 1919. In a short time, he established in Warsaw a leading medical centre. He was also the dean of the Medical Faculty in 1923. He left the department due to age but was graded a title of honorary professor and continued private practice in Warsaw. Professor Głuziński died in Warsaw on April 10 ${ }^{\text {th }}, 1935$ [5-8].

The early research of Professor Głuziński were focused on the function of adrenal and thyroid glands, plants containing glycosides, toxicity of diphtheria toxin and antipyretic drugs [9-15]. In 1896, he published a monograph in Polish "Zarys ogólnej patologii i terapii gorqczki" ("An outline of general pathology and therapy of fever") (Cracow, 1896) [16]. He described a new test for bilirubin (1897) [17-18] and experimentally proved that ligation of the coronary artery led to cardiac arrest (1895) [19]. In Cracow Professor Głuziński was co-working in the Department of Internal Medicine under Prof. Eduard John Sas-Korczyński (1844-1905). Prof. Sas-Korczyński and especially Professor Valerian Jaworski (1849-1924) worked in the field of gastroenterology [21-22]. Their works influenced research interest of Professor Głuziński. He worked on pathophysiology of the stomach. This subject of research was continued when Professor Głuziński became a head of the Department of Medicine at the Lvov University and later in Warsaw.

He published about 100 papers. The most important clinical research was focused on pathophysiology, diagnostics and therapy of diseases of the stomach. He described a test, known as "the Gluziński's test" used for a few decades in diagnostics of stomach cancer [23-28]. Professor Głuziński worked also on cardiology. He published a handbook of cardiovascular diseases (as a part of the handbook "Internal diseases" edited by Valerian Jaworski, Cracow 1905) [29]. He also published papers in haematology, nephrology, endocrinology, tuberculosis and others [30-31].

Professor Głuziński is remembered as a talented teacher. He created "a school" consisting of his co-workers. In Cracow, a famous neurophysiologist Adolph Beck (1863-1942) carried out research under Głuziński. Several co-workers became famous internists, from the Lvov period of Gluziński activities: Julius Marichler (1869-1931), Roman Rencki (1887-1941), Marian Franke (18771944), Witold Ziembicki (1874-1950), John Grek (1875-1941), from Warsaw: Włodzimierz Filiński, Zdzisław Górecki, Jacob Węgierko and many others. 
The idea of organization of a meeting of Polish internists can be found in a number of papers or addresses given at the meetings of various societies in the last decade of the $19^{\text {th }}$ century. The earliest known is dated 1892 [32-33]. Finally, in the concluding decree of the $9^{\text {th }}$ Congress of Polish Physicians and Naturalists in 1900, one can read " $a$ section referring to internal disorders should be an independent part of the next congress". The next congress was intended to be held in Poznan (Posen), the city in the part of Poland partitioned by Germany. Despite several efforts, the German authorities did not agree to held the congress and the $10^{\text {th }}$ Congress of Polish Physician and Naturalists was hold in Lvov, in the part of the country partitioned by Austrian Empire. There restrictions against Poles were lower and some cultural events were allowed to take place. In 1906, Professor Gluziński summarised the organizational works. A Session of Internal Diseases was hold as a part of the $10^{\text {th }}$ Congress of Polish Physician and Naturalists in Lvov on July 22-25, 1907 [34]. This session has been considered as the first congress of the association of Polish internists. The organization was finally, established later in 1909 during the first independent and de facto the second congress of Polish internists. The meeting was held in Cracow on July 19-21, 1909 [35-36]. During the meeting the association, Society of Internists of the Polish Land (Towarzystwo Internistów Ziem Polskich) was founded. Because there was no indepent Polish State, it was forbidden to use the name "Society of Polish Internists" and the name "... of Polish Lands" was used. Professor Gluziński was the president of the Session of Internal Diseases (de facto the first congress of Polish intemists) in 1907 and the president of the congress in 1909. He managed all scientific preparation to this meeting.

Professor Gluziński became the president of the Society of Internists of the Polish Lands and significantly contributed to the next two congresses in 1911 and 1914. The last one was held a few days before the outbreak of the First World War. The war interrupted the activities of the society. The $5^{\text {th }}$ Congress was held in Vilna in 1923 for the first time in the independent Poland. During this meeting, the name of the society was changed to Polish Society of Internal Medicine (Towarzystwo Internistów Polskich) (literally Association of Polish Internists). The first issue of the society journal Polskie Archiwum Medycyny Wewnętrznej (Polish Archives of Internal Medicine) appeared during the congress [37]. Professor Gluziński was spiritus movens of all these events. He was the editor-in-chief and founder of the journal. Professor Gluziński was elected to the post of the president of the Polish Society of Internal Medicine. He was on the post until 1925 . He was also the editor-in-chief of the Polish Archives of Internal Medicine until 1926.

In 1927, Professor Głuziński was elected a honorary member of the society and honorary president. In this year, according to decree of the General Assembly of the society, the statement "Journal founded by Professor Ghuzinski" was printed in each copy of the journal. This statement can by found in all currently issued copies as well. 


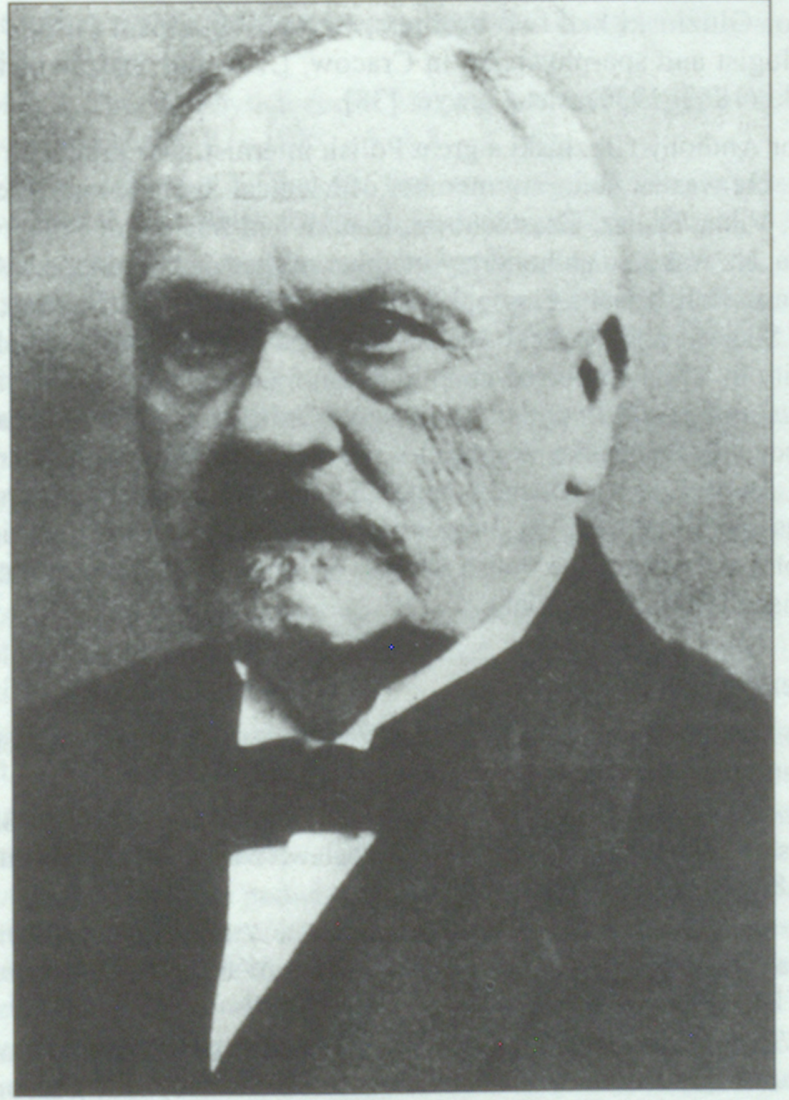

Professor Anthony Głuziński, photo made about 1930 (Reprinted from Polskie Archiwum Medycyny Wewnetrznej 1935 , vol. 14, p. 517) 
Professor Anthony Głuziński was married to Sophia Sokołowska. Their children were: Thadeus Valerian Casimir Głuziński (1888-1940), a famous journalist, Mary Głuzińska, a wife of a famous internist, Zdzisław Szczepański, Lech Głuziński, a physician who was killed during the war (1918), Jane Głuzińska, a second wife of the famous Polish writer Cornelius Makuszyński, and Casimir Głuziński, an industrialist.

Professor Gluziński had two brothers, Lesław Głuziński (1858-1932) was laryngologist and spa-physician in Cracow, Lvov and Szczawnica, Thadeus Głuziński (1863-1930) was a lawyer [38].

Professor Anthony Głuziński a great Polish internist, was granted a number of honours. He was an honorary member of Medical Societies in Cracow, Lvov, Warsaw, Vilna, Kalisz, Częstochowa, Radom and Society of Polish Physicians of Silesia. He was also an honorary member of the Medical Student Association in Warsaw, Polish Balneologigal Society, Czech Medical Society, Yugoslav Medical Society, and Medical Society of Croatia and Slovenia. Stephan Batory University in Vilna conferred upon him honorary doctorship. He was a knight of the Polonia Restituta Order, Saint Sawa Order, and the White Eagle Order. On his seventieth birthday a special issue of Polska Gazeta Lekarska (Polish Medical Journal) was published containing about hundred of papers dedicated to Professor Głuziński [39]. Professor Głuziński was also honoured by his picture on the medal of the Polish Society of Internal Medicine among the most distinguished Polish physicians.

\section{References}

1. Kośmiński S. Słownik lekarzów polskich (Dictionary of Polish physicians). - Warszawa: Gebethner i Wolff, 1888. - P. 144.

2. Szumowski $W$. Głuziński, Franciszek Maciej Jan // Polski Słownik Biograficzny (Polish Biographical Dictionary). - Wroclaw; Warszawa: Ossolineum, 1959. Vol. 8. - P. 86.

3. Brzozowski S. M.: Piotrowski, Gustaw senior // Polski Słownik Biograficzny (Polish Biographical Dictionary). - Wroclaw; Warszawa: Ossolineum, 1965. Vol. 12. - P. 469-470.

4. Kaulbersz J. Napoleon Cybulski // Sześćsetlecie medycyny krakowskiej (Six centuries of medicine in Cracow). Tochowicz L. (ed). - Kraków: Akademia Medyczna, 1964. - Vol. 1. - P. 215-229.

5. Kucharz E. J. Profesor Antoni Głuziński // Polskie Archiwum Medycyny Wewnętrznej. - 1993. - Vol. 90. - P. 375-379.

6. Szumowski W. Gluzinski, Władyslaw Antoni: Polski Słownik Biograficzny (Polish Biographical Dictionary). - Wrocław; Warszawa: Ossolineum. - 1959. Vol. 8. - P. 84-86.

7. Franke M. Śp. Prof. dr. Antoni Głuziński (Obituary) // Polska Gazeta Lekarska. - 1935. - Vol. 14. - P. 325-326. 
8. Franke $M$. Wspomnienie pośmiertne (Obituary) // Polskie Archiwum Medycyny Wewnetrznej. - 1935. - Vol. 14. - P. 517-530.

9. Ghuzińśki A. Kilka słów w sprawie działania wyciągów z nadnercza. (A few remarks on activity of the extracts of suprarenal gland) // Gazeta Lekarska. 1895. - Vol. 30. - P. 371-374.

10. Gluzinski A. O działaniu fizjologicznym wyciągów z nadnercza (Physiological activity of the extracts of the suprarenal gland) // Przegląd Lekarski. - 1895. Vol. 34. - P. 124-125.

11. Ghuziński A. Über die physiologische Wirkung der Nebennierenextracte // Wiener klinische Wochenshrift. - 1895. - Vol. 8. - P. 251.

12. Ghuziński A., Lemerger I. Über den Einfluss der Schilddrüsensubstanz auf den Stoffwechsel // Centralblatt für Innere Medizin. - 1897. - Vol. 17. - P. 89-101.

13. Gtuziński A. Gorzykwiat wiosenny i konwalija majowa jako leki zastępujące naparstnice (Golden seal and lily of the valley as plants substituting digitalis) // Przegląd Lekarski. - 1884. - Vol. 23. - P. 601-603; 619-621; 629-631; 643-645.

14. Ghuzinski A. W sprawie działania jadu błoniczego (On activity of dyphtheria toxin) // Przegląd Lekarski, 1896. - Vol. 35. - P. 349-352.

15. Gtuziński A. Keton salicylowo-resorcynowy jako środek przeciwgorączkowy. (Salicylo-resorcinic keton as a antipyretic drug) // Przegląd Lekarski. 1883. Vol. 22. - P. 673-674.

16. Ghuziński A. Zarys ogólnej patologii i terapii gorączki (An outline of general pathology and therapy of fever). - Kraków: Wydawnictwo Dzieł Lekarskich Polskich, 1896. - P. 8+120+4.

17. Gtuzinski A. Eine neue Reaction auf Gallenfarbstoffe // Wiener kliniche Wochenschrift. - 1897. - Vol. 10. - P. 1139-1140.

18. Ghuziński $A$. Nowa próba na barwniki źólciowe (New test for bilirubin derivatives) // Przegląd Lekarski. - 1897. - Vol. 34. - P. 653-654.

19. Ghuziński A. O wpływie podwiązania tẹtnic wieńcowych na narząd nerwoworuchowy serca (On the influence of ligation of coronary arteries on the stimulatory system of the Heart) // Rozprawy Akademii Umiejętności: Wydział Matematyczno-Przyrodniczy. - 1895. - Vol. 9, ser. 2. - P. 330-348.

20. Aleksandrowicz J., Lisiewicz J. Edward Korczyński // Sześćsetlecie medycyny krakowskiej (Six centuries of the medicine in Cracow), Tochowich L. (ed.). Kraków: Akademia Medyczna, 1964. - Vol. 1. - P. 157-170.

21. Skulimowski M. Jaworski, Walery // Polski Słownik Biograficzny (Polish Biographical Dictionary). - Wrocław; Warszawa; Ossolineum, 1960. - Vol. 11. - P. 113-115.

22. Hanecki M. Walery Jaworski // Polski Tygodnik Lekarski. - 1975. - Vol. 30. P. 581-583.

23. Ghuziński A. O wczesnem rozpoznawaniu raka żołądka (On early diagnosis of the gastric cancer) // Gazeta Lekarska. 1902. - Vol. 37. - P. 34 44; 63-69;91-99. 
24. Ghuziński A. Dalsze spostrzeženia nad moją metodą rozpoznawania charakteru cieśni odzwiernikowej, względnie przechodzenia wrzodu okrągłego zołądka w raka (Further studies on my method for diagnosis of the stenosis pylori and transformation of the round ulcer to cancer of the stomach) // Księga pamiątkowa 250-lecia załoženia Uniwersytetu Lwowskiego (A Commemorative Book on the $250^{\text {th }}$ Anniversary of Foundation of the Lvov University). - Lwów, 1911. - P. 30.

25. Ghuziński A. O leczeniu przewlekłych cierpień żołądka połączonych z nadmierną kwaśnością i nadmiernym wydzielaniem soku żołądkowego (Treatment of chronic disorders of the stomach associated with hyperacidosis and hypersecretion of the gastric juice) // Lwowski Tygodnik Lekarski. - 1910. - Vol. 5. - P. 1-5.

26. Ghuziński $A$. Uwagi nad etjologią, patogenezą i rozpoznawaniem wrzodu dwunastnicy (Remarks on etiology, pathogenesis and diagnostics of the duodenal ulcer) // Przegląd Lekarski. - 1917. - Vol. 56. - P. 1-5; 13-16; 21-22.

27. Ghuzinski A. Uwagi nad tzw. wrzodziejącym zapaleniem kiszki grubej i stosunku tego cierpienia do czerwonki (Colitis ulcerosa and its relation to shigellosis) // Przegląd Lekarski. - 1917. - Vol. 56. - P. 203-205, 214-215.

28. Ghuziński A., Jaworski W. De l'hypersecretion et de l'hyperacidité du suc gastrique // Archives Slaves de Biologie. - 1887. - Vol. 4. - P. 84-92.

29. Ghuziński A. Choroby serca i naczyń krwionośnych (Diseases of the heart and blood vessels) // Nauka o chorobach wewnętrznych (Internal medicine) // Jaworski W. (ed.). - Kraków, 1905. - Vol. 2.

30. Ghuziński A. Przyczynek do znaczenia klinicznego wydzielania się chlorków w chorobach nerkowych (Clinical significance of chloride excretion in renal disorders) // Gazeta Lekarska. - 1908. - Vol. 93. - p. 323-327; 355-362; 384-388; 407-409; 420-422.

31. Ghuziński A. Über das Verhalten der Chloride im Harn bei Magenkrankheiten /I Berliner Klinische Wochenschrift. - 1887. - Vol. 24. - P. 983-985.

32. Korczyński E. Wniosek tyczący się odbywania corocznych zjazdów internistów polskich (Proposal of organization of annual congresses of Polish internists) // Dziennik VI Zjazdu Lekarzy i Przyrodnikow Polskich (Proceedings of the $6^{\text {th }}$ Congress of Polish Physician and Naturalists). - Kraków, 1891. - Vol. 5. - P. 20.

33. Kucharz E. J. "Pradzieje" Towarzystwa Internistów Polskich (Early history of the Polish Society of Internal Medicine) // Polskie Archiwum Medycyny Wewnętrznej - in press.

34. Dziennik X Zjazdu Lekarzy i Przyrodników Polskich. XII Sekcja medycyny wewnetrznej (Proceedings of the $10^{\text {th }}$ Congress of Polish Physicians and Naturalists. Section XII. Internal medicine) Sieracki S. (ed). - Lwów, 1907. - P. 118-138.

35. Mutermilch $S$. I Zjazd Internistów Polskich. (The $1^{\text {st }}$ Congress of Polish Internists) // Medycyna i Kronika Lekarska. - 1909. - Vol. 44. - P. 764-768.

36. I Zjazd Internistów Polskich (Proceedings of the 1st Congress of Polish Internists) // Przegląd Lekarski. - 1909, supplement.

37. Ghuziński A., Pawinski J., Szczepański Z., Bronowski S., Zebrowski E. Przedmowa (Preface)// Polskie Archiwum Medycyny Wewnętrznej. - 1923. - Vol. 1. - P. 1-2. 
38. Szarejko P.: Gluziński, Lesław // Słownik lekarzy polskich XIX wieku (Dictionary of Polish physicians of the $19^{\text {th }}$ century). - Warszawa: Towarzystwo Lekarskie Warszawskie, 1991. - Vol. 1. - P. 207-209.

39. Rencki R., Marichler J. Władyslaw Antoni Głuziński // Polska Gazeta Lekarska. - 1927. - Vol. 6. - P. 753-757.

\section{Summary}

Professor Anthony Głuziński (1856-1935) was one of the greatest Polish internists of the turn of the $19^{\text {th }}$ and $20^{\text {th }}$ century. He was the son of a physician and greys in strong Polish tradition. After graduation at the Jagiellonian University, he worked at the Department of Pathology and Department of Internal Medicine in Cracow. In 1897-1919, he was a head of the Department of Internal Medicine in Lvov. Since 1919, he was a head of the Department of Internal medicine at the Warsaw University, - the capital of independent Poland.

Professor Głuziński left a number of papers in pathophysiology and especially in internal medicine including those in gastroenterology, cardiology, pulmonology, nephrology and other branches of medicine.

Professor Głuziński was a founder of the Polish Society of Internal Medicine, the president of the society for the first two decades, the founder and the first editorin-chief of the Society journal Polish Archives of Internal Medicine.

Eugene J. Kucharz, $M D, P h D$, Professor of Medicine Al. Korfantego 28/86, PL 40-004 Katowice, Poland 


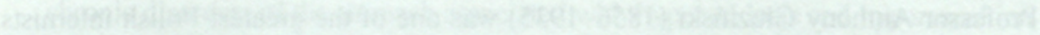

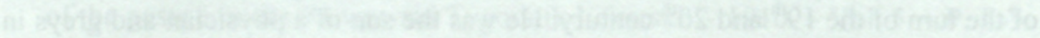

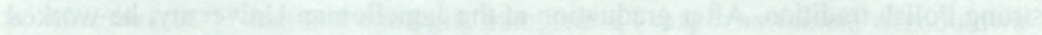

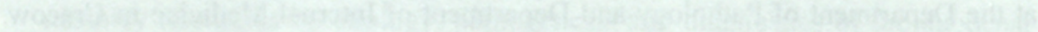

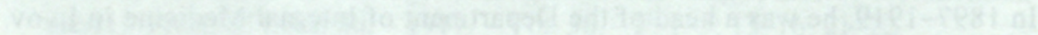

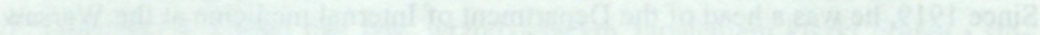

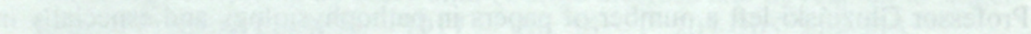

